\title{
Cervical Hydatidiform Moles Pregnancy: Diagnosis and Treatment
}

\author{
I Gde Sastra Winata*iD, Popy Kusuardiyanto(iD, Made Bagus Dwi Aryana ${ }^{(i D}$, Ryan Mulyana \\ Department of Obstetrics and Gynecology, Faculty of Medicine, Universitas Udayana, Sanglah General Hospital, Bali, Indonesia
}

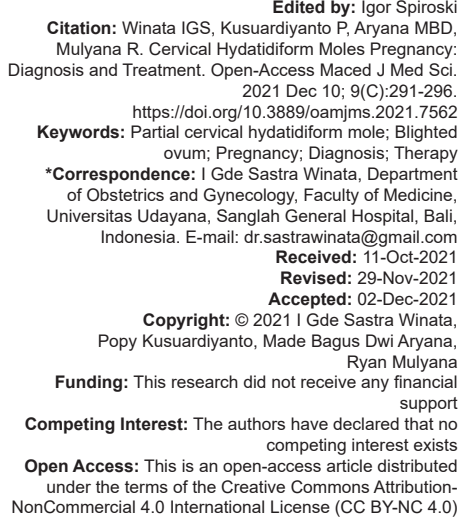
Citation: Winata IGS, Kusuardiyanto P, Aryana MBD Mulyana R. Cervical Hydatidiform Moles Pregnancy Diagnosis and Treatment. Open-Access Maced J Med Sci. 2021 Dec 10; 9(C):291-296.
https://doi.org/10.3889/oamjms. 2021.7562 Keywords: Partial cervical hydatidiform mole; Blighted ovum; Pregnancy: Diagnosis: Therapy ovum; Pregnancy; Diagnosis; Therapy
*Correspondence: I Gde Sastra Winata, Department of Obstetrics and Gynecology, Faculty of Medicine Universitas Udayana, Sanglah General Hospital, Bali, Indonesia. E-mail: dr.sastrawinata@gmail.com Received: $11-$ Oct-2021
Revised: $29-$ Nov-2021 Revised: 29-Nov-2021 Copyright: ๑ 2021 Accepted: $02-\mathrm{Dec}-2021$ Popy Kusurardiyanto, Made Bas Sastra Winata, Popy Kusuardiyanto, Made Bagus Dwi Aryana, Funding: This research did not receive any financial Competing Interest: The authors have declared that no competing interest exists Open Access: This is an open-access article distribute under the terms of the Creative Commons Attribution-
NonCommercial 4.0 International License (CC BY-NC 4.0)

\author{
Abstract \\ BACKGROUND: Cervical partial hydatidiform mole is a rare condition and difficult to diagnose. \\ CASE DESCRIPTION: A 39-year-old Balinese woman from Sanglah General Hospital, Bali, Indonesia, complained \\ vaginal bleeding with abdominal pain. The patient was diagnosed with a partial hydatidiform mole based on physical \\ examination, ultrasound, beta-human chorionic gonadotropin (HCG) levels, and pathology examinations. Mass \\ evacuation surgery followed by arterial ligation to stop the bleeding and periodically examination of beta-HCG levels \\ was carried out until the $14^{\text {th }}$ week after the procedure. Beta-HCG decreased gradually to normal level and indicates \\ no risk of trophoblastic malignancy. \\ CONCLUSION: Establishing the early diagnosis significantly affects the outcome of patient.
}

\section{Introduction}

Hydatidiform mole (gestational trophoblastic disease) is a trophoblastic disease that usually occurs in pregnancy, characterized by the growth of abnormal trophoblast tissue. This disease can appear as a benign or malignant disease [1]. The incidence rate of hydatidiform mole in Indonesia was quite high, up to $13.0 / 1000$ pregnancies. This rate was higher than other countries such as Taiwan at (8.0/1000 pregnancies), the Philippines (5.0/1000 pregnancies), and China (1.9-4.9/1000 pregnancies) [1], [2]. The least common incidence was in North America, Europe, and Oceania, ranging from 0.5 to $1.84 / 1000$ pregnancies. The most important risk factor for hydatidiform mole is maternal age $>35$ years or $<20$ years. Other risk factors such as previous molar pregnancies, genetic factors, and dietary and socioeconomic factors [1].

Two types of hydatidiform mole based on anatomy pathology examination are complete and partial type. The incidence of malignant transformation (invasive mole, choriocarcinoma, or placental site trophoblastic tumor [PSTT]) was higher in complete type (16\%) than partial type $(0.5 \%)$ [3], [4]. Choriocarcinoma may also be contributed by an aborted or a term pregnancy that occurs several years later as a metastatic disease with elevated beta-human chorionic gonadotropin (hCG) even with normal pelvic ultrasound findings [4], [5], [6].

Hydatidiform mole is difficult to diagnose clinically because its signs and symptoms are non-specific. An increase in quantitative beta-hCG levels occurs in hydatidiform moles, meanwhile, it also elevated in normal pregnancies, especially in multiple pregnancies. Ultrasound plays an important role in differentiating mole from a normal pregnancy. However, ultrasound image sometimes resembles a blighted ovum with a gestational sac that has a thin echogenic layer and smaller than the expected size for gestational age [3]. In fact, hydatidiform mole is often not suspected until histopathological examination is performed [7]. Difficulty in diagnose this disease often delays the management of patient, thus affecting the prognosis. Therefore, in this case report, we will discuss the challenges in diagnosis and management of partial cervical hydatidiform mole.

\section{Case Report}

A 39-year-old Balinese woman came to Sanglah General Hospital, Bali, Indonesia, with 
complaints of vaginal bleeding, abdominal pain, weakness, and dizziness. Seventeen days before, the patient was diagnosed with blighted ovum based on clinical examination and investigations (Figure 1) and curettage was done. The patient had active bleeding from the cervical tear at 5, 6, and 12 o'clock which was then performed with primary hecting/cervical ligation.

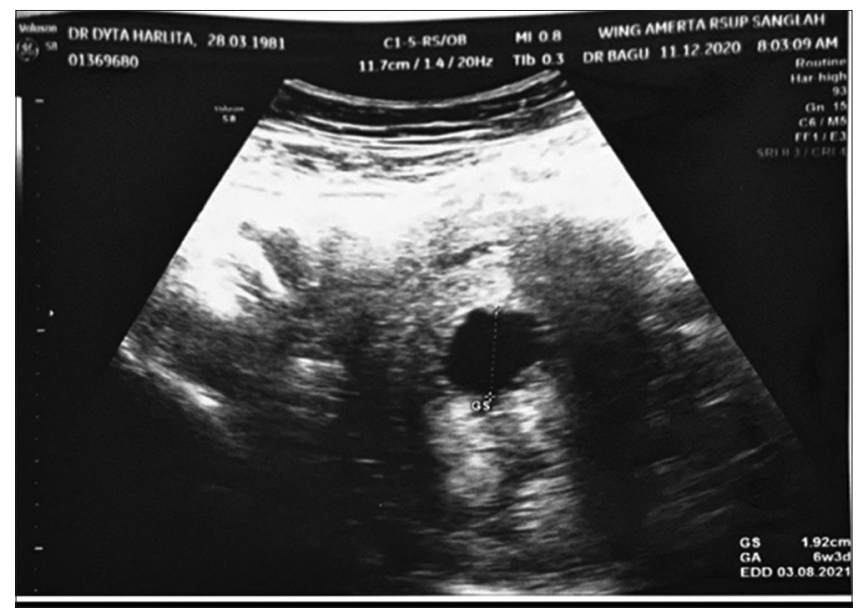

Figure 1: The ultrasound image shows the appearance of a blighted ovum

Gynecological examination showed active bleeding from the OUE and the cervix was sutured. The patient then underwent a transvaginal ultrasound examination (Figure 2). The result shows complex mass area on cervix and suspected as cervical cancer.

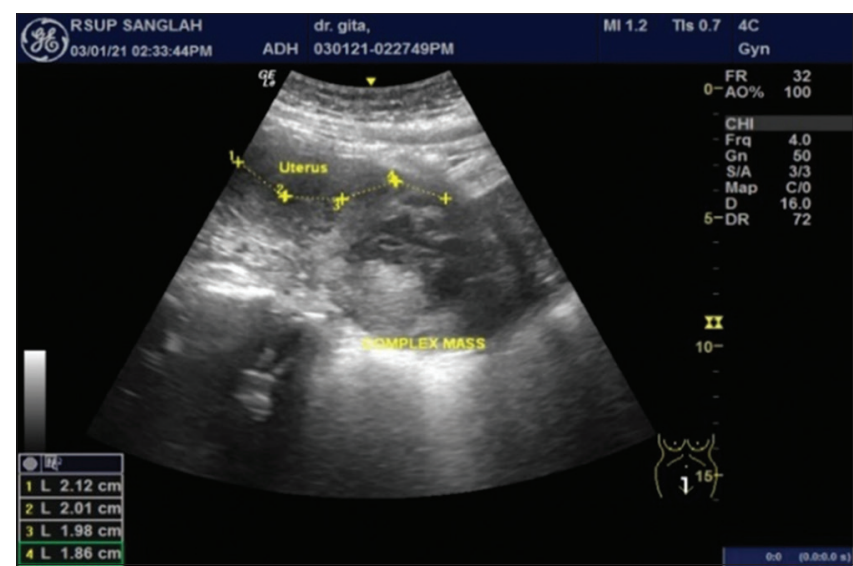

Figure 2: Transvaginal ultrasound image showing the complex mass area of the cervix (yellow arrow)

The patient underwent exploratory laparotomy for the purpose of diagnosis and therapy. Evaluation during the operation showed no hemoperitoneum, large uterus, and normal consistency, both tubes and ovaries were normal, and palpable intracervical mass. The right and left internal iliac (hypogastric) arteries were identified and ligated. Followed by evacuation of the intracervical mass, obtained $\pm 50 \mathrm{~g}$ of tissue and then sent for histopathology examination. Evaluation after evacuation of the intracervical mass did not reveal active bleeding (-) followed by tamponade with a balloon Foley catheter.
The results of histopathology examinations on mass preparations in the cervix can be explained macroscopically and microscopically. Macroscopically: Received one piece of preparation in a small plastic container, containing pieces of tissue. The overall size is $7.5 \times 7 \times 2 \mathrm{~cm}$; the largest size is $3 \times 2.5 \times 1.5 \mathrm{~cm}$. Irregular shape, partly brownish-white-gray color, elastic consistency, and partly brittle.

Microscopically, the preparation contains pieces of tissue consisting of large areas of fibrin deposition, areas of hemorrhage, and areas of necrosis. Among them were foci of stromal foci that experienced decidual reactions containing polymorphonuclear and mononuclear inflammatory cell infiltrates and foci of necrosis. Villi chorealis, scattered in various shapes and sizes, are lined by cytotrophoblast cells and focal proliferative syncytiotrophoblast. The villi chorealis cshow partly avascular edematous villi, partly with a central cisterna. There were also fragments of stratified squamous surface epithelium without connective tissue stroma and no signs of atypia. This histomorphology is suitable for partial hydatidiform mole.

Medication therapy included antibiotics (cefixime and metronidazole), analgesics, and iron supplement. The patient was discharged for polyclinic control after 5 days of hospitalization. Examination of beta-HCG levels was carried out periodically (Table 1). There was a significant decrease in beta-HCG levels, therefore, the risk of malignancy was minimal and chemotherapy was not given to the patient.

Table 1: Results of monitoring of beta-HCG levels

\begin{tabular}{ll}
\hline Weeks after evacuation procedure & Beta-HCG level $(\mathrm{mlU} / \mathrm{mL})$ \\
\hline Day 1 & 595.40 \\
2 & 39.45 \\
4 & 7.77 \\
6 & 2.80 \\
8 & 0.45 \\
10 & 0.28 \\
12 & $<2.30$ \\
14 & $<2.30$ \\
\hline HCG: Human chorionic gonadotropin.
\end{tabular}

\section{Discussion}

Hydatidiform mole is a trophoblastic disease in pregnancy characterized by abnormal proliferation of trophoblasts and hydrops villi; several factors increase the risk of hydatidiform mole [8]. Maternal age is the most important risk factor. Women aged over 35 years and adolescents significantly increased the risk of hydatidiform mole with a risk of 1.5-2.0 in women younger than 20 years, 2.5 times in women aged 35 years, and 5 times in women over than 40 years [1], [9]. In this case, the patient was 39 years age which was at risk for a molar hydatidiform pregnancy.

Women with a previous history of molar pregnancy had a $13 \%$ risk of having a molar pregnancy 
again [10]. The patient in this case had no previous history of hydatidiform mole pregnancy. Genetic factors may also play a role in about $0.6-2.57 \%$ of the total incidence of hydatidiform mole. Mutations in the NLRP7 or KHDC3L gene have a genetic etiology [1], [11], [12], [13], [14], [15], [16]. Diet and socioeconomic factors are also as contributing factors. Oral contraceptive use, gravida, parity, smoking, exposure to herbicides, paternal age, and viral infection were not associated with this disease [1]. The patient underwent previous curettage because of blighted ovum. Cervical-uterine instrumentation is a predisposing factor for ectopic pregnancy including cervical hydatidiform mole [17].

Hydatidiform mole is the result of abnormal fertilization. A complete hydatidiform mole occurs when a single haploid sperm fertilizes an ovum without chromosomes. Fertilization is followed by chromosomal duplication and formation of a zygote without maternal genetic material, resulting in a diploid zygote. While in partial type, usually has a triploid chromosome pattern of as a result of fertilization of a normal egg cell by two sperm cells [4], [5], [6]. The most common chromosome patterns are $69 \mathrm{XXX}, 69 \mathrm{XXY}$, and $69 \mathrm{XYY}$, all of these types come from paternal [1], [2], [10]. In this case, the genetic material of the zygote was not examined because the patient at the first visit had a curettage with a diagnosis of blighted ovum and had not been considered for a hydatidiform mole.

The diagnosis of hydatidiform mole is established through history taking, physical examination, and investigations (quantitative beta-hCG examination, pelvic ultrasound, and histopathology examination). Clinically, hydatidiform mole is difficult to diagnose because the signs and symptoms are not specific. Patients usually come in pregnant with complaints of irregular vaginal bleeding, severe nausea and vomiting, expulsion of vesicles resembling grapes, uterine enlargement, clinically resembling preeclampsia, anemia, or hyperthyroidism [5], [18]. The previous case reports of hydatidiform mole also complained of heavy vaginal bleeding, which lasts 1-2 months, and mainly occurs after curettage [17], [19]. This patient also complained of profuse vaginal bleeding and was previously diagnosed with a blighted ovum and underwent curettage.

The most gestational trophoblastic neoplasia (GTN) secretes beta-hCG hormone, therefore, an increase in its level supports diagnosis of hydatidiform mole. However, some types of choriocarcinoma and bimorphic tumors also secrete beta-hCG in low titers [20] while the PSTT shows intermediate neoplastic proliferation [4]. In this case, the first examination of beta-hCG levels was performed on day 18 after curettage and beta-hCG levels were $595.40 \mathrm{mIU} / \mathrm{ml}$. This level is still appropriate for a pregnancy over 5 weeks of gestational age. Two previous case reports showed that beta-hCG levels of hydatidiform mole patients were around 8320 and $13,155 \mathrm{IU} / \mathrm{L}$. This level was lower than the results in this study [17], [19].
Investigation with ultrasound in the first trimester of pregnancy is important to assist diagnosis of hydatidiform mole if there are clinical suspicion and abnormal increase in beta-hCG level. This examination can be performed transvaginal or transabdominal. In gestational trophoblastic neoplasms, myometrial invasion is better examined by transvaginal ultrasound method because the interface between the trophoblastic tissues section with the myometrium can clearly visualized [3].

Hydatidiform mole appears as a heterogeneous endometrial mass with variable echogenicity in ultrasound [4], [6], [21]. Classically, it presents as a snow storm or granular appearance because there are multiple foci of echogenicity [3]. Fluid-filled mole vesicles vary in size from 1 to $30 \mathrm{~mm}$ which will appear as a small anechoic space. The size of the anechoic space will get bigger and more numerous with increasing gestational age [2], [6]. The image of ultrasound sometimes resembles a blighted ovum with a structure of gestational sac and a thin echogenic layer, smaller than the expected size for gestational age [3]. In this case, ultrasound shows complex mass area which was no typical ultrasound. The previous ultrasound image with the presence of a gestational sac suggested a partial mole that had not been previously identified and suspected a blighted ovum.

The disadvantage of ultrasound examination is inability to certainty determine the level of malignancy. Computed tomography (CT) scan is usually needed to detect metastases of this disease. On examination, it is usually seen as an enlarged uterus with focal irregular lesions or enlargement of both ovaries with multiple theca lutein cysts. Vascular malformations due to trophoblastic neoplasia may also be seen on CT scans. Magnetic resonance imaging examination is not used as a routine examination in hydatidiform moles, but sometimes useful to help determine the depth of invasion into the myometrium [3]. Histopathological examinations should be performed as the gold standard to confirm the diagnosis.

Pathologically, hydatidiform mole consists of abnormal proliferation of syncytiotrophoblast and cytotrophoblast which then cause swelling of the chorionic villi. Complete mole shows severe swelling of the villi resembling grapes but no embryo. Swelling of the villi is milder in partial moles and usually an embryo is formed. The choreal villi partially show an avascular edematous villus, some with a central cisterna [3]. In this case, a histopathological examination showed a partial hydatidiform mole in the cervix.

The preferred treatment is evacuation by vacuum curettage and medical evacuation is alternative method. Sharp curettage is not recommended to prevent the risk of uterine perforation [7]. Pregnancy testing with urine samples is performed 3 weeks after medical management if the tissue sample is not histologically examined [7], [12]. Treatment of hydatidiform moles with 
vacuum evacuation has a cure rate of $84 \%$ in complete moles and $99.5 \%$ in partial type mole. The readiness of blood components is a consideration in anticipating massive bleeding [3].

In choriocarcinoma and invasive mole, chemotherapy is the mainstay of treatment. This malignancy is chemosensitive, especially if detected at an early stage and classified correctly [3], [4], [6], [20], [22]. In the low-risk group, single chemotherapy with methotrexate or actinomycin-D is recommended (Table 2). While in the high-risk group, EMA-CO combination chemotherapy (etoposide, methotrexate, actinomycin-D, cyclophosphamide, and vincristine) was preferred [3]. In a cervical partial hydatidiform mole, methotrexate is a reported successful treatment [22], [23], [24].

Table 2: Scoring system from the WHO and International Federation of Gynecology and Obstetrics for risk of gestational trophoblastic tumor

\begin{tabular}{|c|c|c|c|c|}
\hline \multirow[t]{2}{*}{ Risk factors } & \multicolumn{4}{|c|}{ Risk score } \\
\hline & 0 & 1 & 2 & 4 \\
\hline Maternal age (year) & $<40$ & $\geq 40$ & - & - \\
\hline Previous pregnancy & Mole & Abortus & A term & - \\
\hline $\begin{array}{l}\text { Interval (between end of the previous } \\
\text { pregnancy-chemotherapy in month) }\end{array}$ & $<4$ & $4-6$ & $7-13$ & $>13$ \\
\hline Beta-hCG level (IU/I) & $<10^{3}$ & $10^{3}-10^{4}$ & $10^{4}-10^{5}$ & $>10^{5}$ \\
\hline Number of metastase & 0 & $1-4$ & $5-8$ & $>8$ \\
\hline Site of metastase & Lung & $\begin{array}{l}\text { Spleen, } \\
\text { kidney }\end{array}$ & $\begin{array}{l}\text { Gastrointestinal } \\
\text { tract }\end{array}$ & $\begin{array}{l}\text { Brain, } \\
\text { liver }\end{array}$ \\
\hline The biggest tumor size & & $3-5 \mathrm{~cm}$ & $>5 \mathrm{~cm}$ & \\
\hline $\begin{array}{l}\text { Previous chemotherapy } \\
\text { Low risk } 0-6 \text {, high risk }>6\end{array}$ & & & Single drug & $\geq 2$ drugs \\
\hline
\end{tabular}

In two case reports, a cervical partial hydatidiform mole was successfully evacuated by cervical curettage. Bleeding stopped after evacuation with curettage and bimanual pressure and a decrease in beta-HCG levels on serial examinations did not require chemotherapy [17]. However, another report of a complete cervical hydatidiform mole was given methotrexate and the bleeding was heavier, requiring vasopressin and balloon tamponade. In addition, this case report also requires chemotherapy to eliminate cells that produce beta-HCG [25].

In this case, management was carried out by evacuation of intracervical masses and controlling the bleeding that occurred with surgery. Evacuation of intracervical masses as a therapy and at the same time as a diagnosis through histopathology examination of the evacuated mass. Installation of vaginal Foley catheter tampons was performed to control the bleeding source area; this tampon was maintained for 48 h. Blood product (packed red blood cell) was also administrated to patient.

The outcome of hydatidiform mole is very difficult to predict at the time of initial diagnosis, therefore, serial quantitative beta-hCG examination is necessary after evacuation to diagnose trophoblastic neoplasia as early as possible [5], [26]. Recommendations International Federation of Gynecology and Obstetrics, GTN posthydatidiform mole is diagnosed according to the following criteria: (1) Beta-hCG levels were constant for 3 weeks in four examinations, days 1, 7, 14, and 21 after evacuation; (2) increased levels of beta-hCG in three consecutive examinations or more in a minimum period of 2 weeks, the $1^{\text {st }}, 7^{\text {th }}$, and $14^{\text {th }}$ day after evacuation; (3) histopathological diagnosis of choriocarcinoma; and (4) elevated beta-hCG levels for 6 months or more after evacuation [27].

Post-therapy follow-up is usually carried out with serial beta-hCG examinations for at least 1 year, although the follow-up protocol varies by center. In this case, follow-up was carried out based on the patient's clinical and beta-hCG levels in the first 3 months (12 weeks after cervical mass evacuation/ cervical curettage) and showed a suitable decrease so chemotherapy was not given. Monitoring of beta-hCG levels will continue for up to 1 year after curettage. The follow-up is done monthly in the second 3 months and every 2 months in the past 6 months. Furthermore, monitoring is carried out at any time based on clinical and beta-hCG levels.

\section{Conclusion}

Cervical hydatidiform mole pregnancy is a rare case. Based on clinical data and supporting examinations in the form of beta-HCG levels, ultrasound, and histopathology, this patient was diagnosed with cervical partial hydatidiform mole. Evacuation of mass and control of bleeding were conducted in this patient. The beta-HCG of the patient showed a significant decrease based on follow-up; therefore, she did not require chemotherapy. The diagnosis of hydatidiform mole is difficult, but the appropriate early diagnosis greatly affects the patient's outcome. A hydatidiform mole should always be suspected when there is supportive clinical sign. Periodic examination of beta-HCG level can be used to help determine the patient's prognosis.

\section{Ethical Consideration}

Signed written informed consent was obtained before data collection from patient regarding publication of their medical data in scientific medical journal.

\section{References}

1. Hui P, Buza N, Murphy KM, Rennett BM. Hydatidiform moles: Genetic basis and precision diagnosis. Annu 
Rev Pathol. 2017;12:449-85. https://doi.org/10.1146/ annurev-pathol-052016-100237

PMid:28135560

2. Salehi S, Eloranta S, Johansson AL, Bergstrom M, Lambe M. Reporting and incidence trends of hydatidiform mole in Sweden 1973-2004. Acta Oncol. 2011;50(3):367-72. https://doi.org/10.3 109/0284186X.2010.512922

PMid:21395467

3. Dhanda S, Ramani S, Thakur M. Gestational trophoblastic disease: A multimodality imaging approach with impact on diagnosis and management. Radiol Res Pract. 2014;2014:842751. https://doi.org/10.1155/2014/842751 PMid:25126425

4. Allen SD, Lim AK, Seckl MJ, Blunt DM, Mitchell AW. Radiology of gestational trophoblastic neoplasia. Clin Radiol. 2006;61(4):301-13. https://doi.org/10.1016/j.crad.2005.12.003 PMid:16546459

5. Elsayes KM, Trout AT, Friedkin AM, Liu PS, Bude RO, Platt JF, et al. Imaging of the placenta: A multimodality pictorial review. Radiographics. 2009;29(5):1371-91. https://doi.org/10.1148/ rg. 295085242

PMid:19755601

6. Jain KA. Gestational trophoblastic disease: Pictorial review Ultrasound Q. 2005;21(4):245-53. https://doi.org/10.1097/01. ruq.0000191658.95192.89

PMid:16344728

7. Sebire NJ, Seckle MJ. Gestational trophoblastic disease: Current management of hydatidiform mole. BMJ. 2008;337:a1193. https://doi.org/10.1136/bmj.a1193 PMid:18708429

8. Hui P, Baergen R, Cheung A, Fukunaga M, Gersell D, Lage JM, et al. Gestational trophoblastic disease. In: Kurman RJ, Carcangiu ML, Herrington CS, Young $\mathrm{RH}$, editors. WHO Classification of Tumours of Female Reproductive Organs. Vol. 6. Geneva: World Health Organization; 2014. p. 155-67.

9. Sebire NJ, Foskett M, Fisher RA, Rees H, Seckl M, Newlands E. Risk of partial and complete hydatidiform molar pregnancy in relation to maternal age. BJOG. 2002;109(1):99-102. https://doi. org/10.1111/j.1471-0528.2002.t01-1-01037.x

PMid:11843379

10. Eagles N, Sebire NJ, Short D, Savage PM, Seckl MJ, Fisher RA Risk of recurrent molar pregnancies following complete and partial hydatidiform moles. Hum Reprod. 2015;30(9):2055-63. https://doi.org/10.1093/humrep/dev169

PMid:26202916

11. Murdoch S, Djuric U, Mazhar B, Seoud M, Khan R, Kuick R, et al. Mutations in NALP7 cause recurrent hydatidiform moles and reproductive wastage in humans. Nat Genet. 2006;38(3):300-2. https://doi.org/10.1038/ng1740

PMid:16462743

12. Qian J, Deveault C, Bagga R, Xie X, Slim R. Women heterozygous for NALP7/NLRP7 mutations are at risk for reproductive wastage: Report of two novel mutations. Hum Mutat. 2007;28(7):741. https://doi.org/10.1002/humu.9498 PMid:17579354

13. Kou YC, Shao L, Peng HH, Rosetta R, del Gaudio D, Wagner AF, et al. A recurrent intragenic genomic duplication, other novel mutations in NLRP7 and imprinting defects in recurrent biparental hydatidiform moles. Mol Hum Reprod 2008;14(1):3340. https://doi.org/10.1093/molehr/gam079 PMid:18039680

14. Williams D, Hodgetts V, Gupta J. Recurrent hydatidiform moles. Eur J Obstet Gynecol Reprod Biol. 2010;150(1):3-7. https://doi. org/10.1016/j.ejogrb.2010.01.003

\section{PMid:20171777}

15. Parry DA, Logan CV, Hayward BE, Shires M, Landolsi $H$ Diggle $\mathrm{C}$, et al. Mutations causing familial biparental hydatidiform mole implicate C6orf221 as a possible regulator of genomic imprinting in the human oocyte. Am J Hum Genet. 2011;89(3):451-58. https://doi.org/10.1016/j.ajhg.2011.08.002 PMid:21885028

16. Reddy R, Akoury E, Nguyen NM, Abdul-Rahman OA, Dery C Gupta N, et al. Report of four new patients with proteintruncating mutations in C6orf221/KHDC3L and colocalization with NLRP7. Eur J Hum Genet. 2013;21(9):957-64. https://doi. org/10.1038/ejhg.2012.274

PMid:23232697

17. Aytan H, Caliskan AC, Demirturk F, Koseoglu RD, Acu B Cervical partial hydatidiform molar pregnancy. Gynecol Obstet Invest. 2008;66(2):142-4. https://doi.org/10.1159/000141647 PMid:18583920

18. Betel C, Atri M, Arenson A, Khalifa M, Osborne R, Tomlinson G Sonographic diagnosis of gestational trophoblastic disease and comparison with retained products of conception. J Ultrasound Med. 2006;25(8):985-93. https://doi.org/10.7863/ jum.2006.25.8.985

PMid:16870892

19. Schwentner L, Schmitt W, Bartusek G, Kreienberg B, Herr D Cervical hydatidiform mole pregnancy after missed abortion presenting with severe vaginal bleeding: Case report and review of the literature. Eur J Obstet Gynecol Reprod Biol. 2011;156(1):9-11. https://doi.org/10.1016/j.ejogrb.2010.12.029 PMid:21272989

20. Hancock BW. Staging and classification of gestational trophoblastic disease. Best Pract Res Clin Obstet Gynaecol. 2003;17(6):869-83. https://doi.org/10.1016/ s1521-6934(03)00073-7

\section{PMid:14614886}

21. Kani KK, Lee JH, Dighe M, Moshiri M, Kolokythas O Dubinsky T. Gestatational trophoblastic disease: Multimodality imaging assessment with special emphasis on spectrum of abnormalities and value of imaging in staging and management of disease. Curr Probl Diagn Radiol. 2012;41(1):1-10. https:// doi.org/10.1067/j.cpradiol.2011.06.002 PMid:22085657

22. Royal College of Obstetricians and Gynaecologists (RCOG). The Management of Gestational Trophoblastic Disease, GreenTop Guideline No. 38. United Kingdom: Royal College of Obstetricians and Gynaecologists; 2010. p. 1-12

23. Kung FT, Chang SY, Tsai YC, Hwang FR, Hsu TY, Soong YK. Subsequent reproduction and obstetric outcome after methotrexate treatment of cervical pregnancy: A review of original literature and collaborative follow up. Hum Reprod. 1997;12(3):591-5. https://doi.org/10.1093/humrep/12.3.591 PMid:9130765

24. Ginsburg ES, Frates MC, Rein MS, Fox JH, Hornstein MD Friedman AJ. Early diagnosis and treatment of cervical pregnancy in an in vitro fertilization program. Fertil Steril. 1994;61(5):966-96. https://doi.org/10.1016/s0015-0282(16)56714-4 PMid:8174738

25. Wee HY, Tay EH, Soong Y, Loh SF. Cervical hydatidiform molar pregnancy. Aust N Z J Obstet Gynaecol. 2003;43(6):473-4. https://doi.org/10.1046/j.0004-8666.2003.00132.x PMid:14712955

26. Ng TY, Wong LC. Diagnosis and management of gestational trophoblastic neoplasia. Best Pract Res Clin Obstet Gynaecol. 2003;17(6):893-903. https://doi.org/10.1016/ s1521-6934(03)00098-1

PMid:14614888 
27. Ngan $\mathrm{H}$, Bender $\mathrm{H}$, Benedet JL, Jones $\mathrm{H}$, Montruccoli GC, Pecorelli S, et al. Gestational trophoblastic neoplasia, FIGO 2000 staging and classification. Int J Gynaecol
Obstet. 2003;3 Suppl 1:175-7. https://doi.org/10.1016/ s0020-7292(03)90120-2

PMid:14763174 